\title{
A Conceptual Model of Organizational Voice with an Interpretive Structural Modeling Approach: A study on Yazd University, Iran
}

\author{
ELAHE HOSSEINI* and MEHDI SABOKRO \\ Department of Business Administration, Faculty of Economics, \\ Management \& Accounting. Yazd University, Yazd, Iran.
}

\begin{abstract}
The present study aims to develop a conceptual model of organizational voice. The statistical population includes experts familiar with the organizational voice. Then, a comprehensive model of levels and the relations among organizational voice dimensions were drawn to be applied using interpretive structural modeling. The research findings introduce 10 dimensions including organizational structure, management and leadership, group and team, voice environment, job characteristics, human resources, conflict, motivation, and communication. Finally, the initial model of the research was drawn in five lines using the interpretiveapproach. The research findings show that experts believe there are 10 important factors in achieving organizational voice. According to the findings, character and management are considered the model foundation and they are the most important factors. The results, as a road map, can guide organization managers to achieve organizational voice. An innovative framework was developed by applying an interpretive structural modeling to propose a model.
\end{abstract}

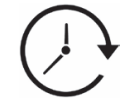

Article History

Received: 05 June 2021

Accepted: 18 July 2021

\section{Keywords}

Interpretive Structural Modeling;

Management;

Organizational Voice, Voice Environment.

\section{Introduction}

Recently, researchers have started to study the negative interpersonal acts of employees in response to mistreatment at the workplace (Rai \& Agarwal, 2018; Xu, Loi\& Lam, 2015). On the other hand, today's organizations are witnessing many changes in their environments. Environments that are more dynamic than before, and have required organizations to provide answers to address this dynamism (Salamzadeh, A., Tajpour, M., \& Hosseini, E. (2020). Exploring the Impact of Social Networks on Entrepreneurial Intention. Media Studies, 15(48), 111-124). In many newly founded organizations, employees avoid expressing their


Management \& Accounting. Yazd University, Yazd, Iran.

Department of Business Administration, Faculty of Economics, (c) (i) 
ideas and concerns about organizational problems (Dyne, Ang\& Botero, 2003). Managers in these organizations need to make the right decisions (Tajpour, M., \& Hosseini, E. (2020). The effect of intelligence and organizational culture on corporate entrepreneurship in Shiraz Gas Compa. Human Resource Management in The Oil Industry, 12(45), 335-354). In fact, while solving their previous and past problems, they will be able to deal with new issues and continue to be efficient and up-to-date by applying new policies and solutions (Hosseini, E., Tajpour, M., Lashkarbooluki, M.(2020). The impact of entrepreneurial skills on manager's job performance. International Journal of Human Capital in Urban Management, 5(4), 361-372. Organizational silence is considered to be one of the most important passive responses done by employees due to mistreatment at the workplace (Rai \& Agarwal, 2017). Considering the current conditions, many organizations assert that the process of innovation has been slow in their workplace (Tajpour, Hosseini\& Salamzadeh, 2020). One reason for weak innovation is the silence due to lack of a suitable space to present new ideas (Gambarotto \& Cammozzo, 2010). Those who are not able to express their ideas, opinions, and information and prefer to be silent, consider themselves as gearwheels in organizational structure with no authority in the process of events in the organization (Hosseini, Saeida Ardekani\& Sabokro, 2020a). Such an assumption of oneself results in a great deal of dissatisfaction, stress, depression and psychological disorders. It also causes individuals to lose interest and commitment to their job (Brinsfield, Edwards \& Greenberg, 2009; Nikmaram et al.,2012; Tangirala \& Ramanujam, 2008). Lack of good practices can impose an unpleasant intra-organization and, thus, it gives the employee more voice (Wilkinson, Dundon, Marchington\& Ackers, 2004).Employee voice enables organizations to learn more about their mistakes and weaknesses (Hosseini, Saeida Ardekani\& Sabokro, 2021a). This, in turn, helps prevent financial and social losses and improves the quality and innovation of the organization's services (Additionally, employee voice is central to high involvement jobs that link Human Resource Management and Performance (Bai, Lin \& Liu, 2019). It's necessary to recognize factors influencing the employee voice to maintain the human capital in organizations and to reduce the negative impact resulting from organizational silence.Employee voice refers to all the ways and means through which employees attempt to have a say about, and influence upon their work and the functioning of their organization (Wilkinson, Barry\& Morrison, 2019). Because no conceptual model has been provided for employee voice in service of organizations so far. Therefore, researchers of the present study are going to design a conceptual model of organizational voice with an approach of interpretive structural modeling and structural equation modeling at Yazd University. Therefore,the purpose of the present study is a conceptual model of organizational voice with an interpretive structural modeling approach at Yazd University in Iran.

\section{Review of the Related Literature}

The emergence and increasing importance of human resources management supported the employee voice in organizations (Dundon \& Gollan, 2007). It has accelerated the emergence of new forms of employee voice, including open door policies that were more participatory (Donaghey, Dundon \& Freeman, 2014). Employees with acquired knowledge absorb new information better than others, which increases business ideas (Nikraftar \& Hosseini, 2017). Employee voice has received attention as a communication strategy (Hosseini \& Sabokro,2021) Hosseini, E., \& Sabokro, M. (2021). A Systematic Literature Review of the Organizational Voice. Iranian Journal of Management Studies.a head of print. The problem is that most organizations they cannot harmonize their methods for getting the voice of their employees (Wilkinson, Dundon, Donaghey\& Freeman, 2014). In order to achieve competitive advantage and continuous development, organizations provide opportunities for employees to express their ideas, opinions and information in the related processes (Moaşa, 2011; Tajpour, Kawamorita\& Demiryurek,2020). Employee voice facilitates expressing suggestions, opinions, concerns and ideas about issues related to work with the aim of improving working environment and organizational processes (Gu, Tang \& Jiang, 2015; Islam, Ahmed, Ali\& Sadiq, 2016). Employee voice refers to the voluntary and sensible description of opinions, suggestions and objections by staff at the working environment (Ruck, Welch \& Menara, 2017). Employee voice has an exclusive point of view regarding civil actions and, moreover, it emphasizes the direct comments from high and low point of view and the horizon which clearly intends to benefit the organization and the group (Hu et al., 
2018). Employee voice takes place directly between management and junior staff or indirectly between management and junior staff representatives (Kim, MacDuffie\& Pil, 2010).

The voice refers to staff comments, information and ideas about changes in the organization and working issues in order to improve the workplace and general process of organization (Islam, Ahmed \& Ali, 2019). The voice emphasizes the constructive criticism for improvement instead of only criticism (Hu, Zhu, Li, Maguire, Zhou, Sun \& Wang, 2018). The voice facilitates trusting employees and makes them feel that organization respects them and appreciates their cooperation (Hosseini et al., 2020b). If organizations allow their employees to present their suggestions and encourage them to help, it will increase job satisfaction among the staff ( Kim, Choi, Borchgrevink, Knutson \& Cha, 2018). In order to extend employees' voice, organizations must provide feeling of empowerment, dependence, responsibility, and an opportunity for the employees to participate more in the process of decision-making(Nikraftar, Hosseini \& Moghadam,2017).

Employees of an organization not only communicate with their superior but also make friends with their junior colleagues (Berman, West, Richter \& Maurice, 2002; Sabokro, Kayedian \& Hosseini, 2021). Considering the social interaction theory and organizational support theory, it seems that such support by the organization and superiors ( managers, leaders, etc.) encourages employees to present their ideas and suggestions in different situations (Islam et al., 2019). This network provides staff interactions and social and emotional support required to encounter tough conditions at the working environment (Konjkav Monfared \& Hosseini, 2020).

One of the most effective factors in organizational voice is managers' well-behavior (Detert \& Burris, 2007; Tajpour, Salamzadeh \& Hosseini,2021). Employees can be more innovative, responsible and independent by the help of their managers (Kalshoven, Den Hartog\& de Hoogh, 2013). Employees who assume that their managers do not pay attention to their ideas, suggestions and opinions, are not motivated enough to present their voice (Dyne et al., 2003; Sabokro, Tajpour \& Hosseini, 2018). Managers create a fair atmosphere and a principal structure, listen to their employees' ideas and join them in the process of decisionmaking (Sagnak, 2017; Rajabipoormeybodi, Hosseini \& Ajorloo,2019). All of these conditions can create an atmosphere at the organization that encourages employees to present their voices (Islam et al., 2019). Moreover, employee voice has an important function to describe the advantage of organizational success and has increased the interests in this subject during the past 20 years (Maynes \& Podsakoff, 2014). Service organizations such as universities, as a heart of a service provider in society with the responsibility of education and training, are regarded as one of the most vital and substantial organizations because of the important function they have (Tajpour, Hosseini\&Alizadeh, 2021). Therefore, they must promote the quality of their human capital continuously (Bordbar, Monfared, Sabokro, Dehghani \& Hosseini, 2021). That's why they require moral and practical managers who help their employees present their intelligence and avoid not to express their professional ideas, views and opinions about the organizational issues and problems and it only happens with the existence of employee voice (Salamzadeh, Tajpour, Hosseini\& Salembrahmi, 2021). However, strategies and policies are made in a way that employees experience less trouble and try their best to focus on their duties and vital roles Tajpour, M., \& Hosseini, E. (2021). Entrepreneurial intention and the performance of digital startups: The mediating role of social media. Journal of Content, Community \& Communication, 13, 2-15. The challenges that organizations face vary according to their activities Salamzadeh, A., \& Tajpour, M. (2021). Identification of the Challenges of Media Startup Creation in Iran. Journal of Entrepreneurship Development, 13(4), 561-580. Most employees complain about lack of good conditions in which they can present their beliefs and express their opinions conveniently that naturally brings about hopeless results. The current research includes the elements considered in previous studies and presents more comprehensive elements. Considering the explanations given above, researchers are about to design a conceptual model for organizational voice with an interpretive structural modeling approach at Yazd University.

Hosseini, Saeida Ardekani \&Sabokro (2021a), Organizations must provide employees with the opportunity to express their ideas, opinions, and information in processes relevant to their work in 
order to gain competitive advantage and continuous development. Constructive suggestions and employee criticism are important for organizations trying to maintain their position in highly competitive environment. The purpose of this study is to investigate the leadership integrity of employees by mediating the empowering behaviors of the leader. Also, thisdescriptive-correlational research is applied in terms of purpose. The statistical population of this study consisted of 460 frontline employee of selected travel agencies in Yazd city and 210 people were selected through the Cochran formula. Data were collected through standard questionnaires. The validity of the questionnaire was evaluated and confirmed by content and construct validity and reliability through Cronbach's alpha coefficient and composite reliability index. The structural modeling technique with PLS 3 software was used for data analysis. The findings of this study show that a leader's behavioral integrity has a positive and significant effect on a leader's empowering behaviors. Leadership behavioral integrity also has a positive and significant effect on employee voices mediated by leader empowering behaviors. Finally, the results showed that the leader's behavioral honesty allows employees to participate in decisions, learn new skills, and enhance their performance, giving them more courage to share their thoughts and ideas with colleagues.

Hosseini, E., Saeida Ardekani, S., Sabokro, M., \& Alhosseini Almodarresi, S. M. (2021). Developing a Model for Knowledge Employee Voice (Case Study: Information Technology Small and Medium Enterprises). Organizational Culture Management. a head of print. by aims to develop a model for knowledge employee voice working in information technology (IT) small and medium enterprises (SMEs) located in science and technology parks affiliated with Iranian universities. This qualitative research is conducted based on the grounded theory model. For this purpose, semi-structured in-depth interviews were performed with 13 individuals including knowledge managers and employees as well as the IT business experts in SMEs affiliated with science and technology parks of Iranian universities given that these companies are accredited by the Ministry of Science, Research, and Technology. The study was conducted in autumn and winter of 2019. The inclusion criteria for the selection of experts consist of having three years of useful occupational experience in SMEs with at least 50 employees. Then, the data were analyzed using Atlas T software version 8 within three stages of initial, axial, and selective coding where the data analysis led to the identification of 8 categories, 16 axial concepts, and 50 final codes. The results showed that the knowledge employee voice can lead to greater interaction with customers, the achievement of competitive advantage, and high productivity and performance in related companies. Moreover, the findings can also help the management improve decision-makings about the obstacles and challenges that the employees may face in the process of growth and development of their companies.

Hosseini, Saeida Ardekani\& Sabokro (2020b), the knowledge employees voice is one of the most important topics that has attracted a lot of attention recently, but there is no evidence based on which the various mechanisms of sound are comprehensive and integrated. Therefore, the purpose of this study is to provide a model of knowledge employee's voice in Shiraz Gas Company. The aim of the present study is of an applied one and the method and identity of the study are regarded as qualitative research approach with a design method of grounded theory. So, using a purposeful and snowball sampling, 15 semi-structured interviews have been held by experts. Then, the Atlas.ti 8 was used to analyze the data. Eventually, at the stage of selective coding, 11 categories along with 44 codes were selected. To ensure the reliability and validity of the research, the findings were confirmed by the interviewees. The results of the research showed that the most important components of the voice of knowledge workers include two levels of organization (management, communication, atmosphere, and voice environment, job characteristics, human resources, organizational structure) and individual level (motivation, personality, group, and team). The most important factor at the organizational, managerial, and individual levels is motivation. Finally, the model of the voice of the knowledge workers was drawn up.

\section{Research questions}

The research questions of the present study are as follows: 
- What are the effective factors of organizational voice at Yazd University?

- What is the communicational model of the effective factors in organizational voice at Yazd University in order to apply the concept?

- What is the fitting model of the effective factors in organizational voice at Yazd University in order to apply the concept?

\section{Methodology}

The present research is regarded as an applied study and its strategies and aim are survey-based and descriptive, respectively. The field method has been used for data collection and it was done by applying the cross-sectional method. The data has been collected through library studies and interviews. The statistical population of the qualitative part has been selected from those experts who were familiar with the organizational voice and interpretive structural model among which 7 persons were chosen according to their experience and their knowledge about the subject according to the judgmental sampling. They had a practical experience of at least 5 years in strategic planning of their organization.

In this type of research plan, qualitative data are given more importance to gain a real insight regarding the issues and the nature of the topic (Cresswell, 1998). This may refer to some authentic experiences pertinent to the issues under examination that are particularly helpful while describing hidden and unanticipated subjects. It can also be influential for specific researches Palalic, R. (2017). The phenomenon of entrepreneurial leadership in gazelles and mice: A qualitative study from Bosnia and Herzegovina. World Review of Entrepreneurship, Management and Sustainable Development, 13(2-3), 211-236. Besides, we decided to apply this method because the core objective is to choose the individuals who are acquainted with such phenomena.

Consequently, it will be easier to comprehend the topic so that the samples can provide appropriate answers accordingly (Hosseini, Saeida Ardekani \& Sabokro, 2020b). It is also recommended because of the objective of the study and the internal judgment. Unlike quantitative studies, qualitative research is less likely to provide arranged procedures, particularly in terms of sampling (Nikraftar, Hosseini \& Mohammadi,2021)

Nikraftar, T., Hosseini, E., \& Mohammadi, E. (2021). The factors influencing technological entrepreneurship in nanotechnology businesses. Revista de Gestão.a head of print

Furthermore, the validity of research instruments was evaluated based on the following steps:

- Validation by participants: they were asked to review the secondary coding stage and provide their opinions accordingly;

- Peer review: respective professors were asked to examine the findings and express their views on the coding process;

- Participatory research: research samples were invited to offer their opinions on the interpretation and analysis of the data; and

- Pluralism: it refers to the variety of participants.

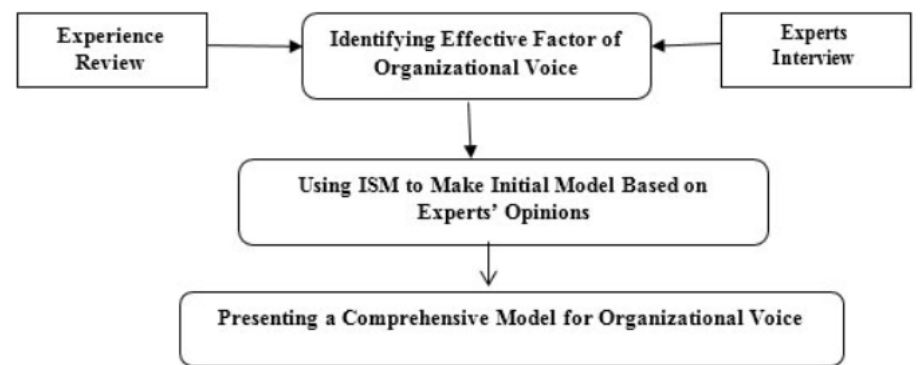

Fig.1: Research Design (Source: Authors' elaboration)

In order to answer the research questions proposed, the present study is organized in a way that appropriate answers are provided and the research stages are shown clearly. The research design of the study is illustrated in Figure1. 
The steps mentioned above must be followed to achieve a comprehensive model, to implement organizational voice and to describe the relationship between the dimensions.

Step1: Identifying factors related to organizational voice: By using Delphi technique, researchers began to identify factors related to organizational voice by extended library studies in the field of organizational voice and comments from 7 university experts including those who have been members of university academic board and masters with experience of being the university manager or manager assistant. Therefore, out of 51 identified factors, 41 were confirmed by the experts.

Step 2: Using interpretive structural model in order to make the initial model for designing conceptual model of organizational voice based on the university experts' suggestions: Interpretive structural model (ISM) is an interactive process that was introduced by Warfield in 1973. In fact, this technique is called interpretive because ISM is a group judgment and the decision is made based on the fact that which factors and how they are related to one another (Aloini, Dulmin, \& Mininno, 2012). ISM psychology assists in creating discipline in complicated relationships between elements of a system. The ISM model recognizes the internal relationship between variables and analyzes the impact of one variable on others. The ISM can also take actions to fulfill the placement of elements in a system which can be helpful for managers to perform the designed model better. Four stages should be generally passed to achieve the target research model using interpretive structural modeling.

\section{A:Identifying Dimensions}

Researchers tried to identify effective factors influencing the concept being surveyed by reviewing the background in the area of voice especially organizational voice and also suggestions presented by 7 organizational experts. Accordingly, 15 factors were identified from all articles related to the present topic. As identified factors are arranged indistinctly and in a disorganized way, researchers started to arrange them in order to equalize the conceptions by making a central group. As a result, the final factors influencing organizational voice has decreased to 10 factors and they are displayed in Table 2.

\section{B:Preparing Questionnaire and Filling by University Experts}

The instruments used in this stage include a questionnaire containing 10 identified factors and the 7 experts as responders are requested to compare the factors two-on-two and specify their relationship (lack of relationship, mutual relationship and onesided relationship)

Table 1. V (if i leads to j), A (if $\mathrm{j}$ leads to i), X (reciprocal effect), $\mathrm{O}$ (no relationships)

\begin{tabular}{|l|l|l|l|l|}
\hline T & G & F & C \\
\hline $\mathrm{O}(4)$ & $\mathrm{X}(3)$ & $\mathrm{A}(2)$ & $\mathrm{V}(1)$ & $\mathrm{X}$ \\
\hline
\end{tabular}

(Source: Authors' elaboration)

1- X has led to C; 2- F has led to X; 3- Both $G$ has led to $X$ and $X$ has led to $G$; and 4 - there is no relationship between $\mathrm{X}$ and $\mathrm{T}$.

D) Developing the initial access matrix: this matrix is formed based on the self-interaction matrix using the following relationships:

- If the cell $(j, i)$ is indicated by the symbol $V$ in the interactive matrix, number 1 would be assigned to the corresponding cell in the access matrix; then number 0 would be assigned to the symmetric cell, i.e. the cell $(i, j)$.

- If the cell $(j, i)$ is indicated by the symbol $A$ in the interactive matrix, number 0 would be assigned to the corresponding cell in the access matrix; then number 1 would be assigned to the symmetric cell, i.e. the cell $(i, j)$.

- If the cell $(j, i)$ is indicated by the symbol $X$ in the interactive matrix, number 1 would be assigned to the corresponding cell in the access matrix; then number 1 would be assigned to the 
symmetric cell, i.e. the cell $(i, j)$.

- If the cell $(j, i)$ is indicated by the symbol $O$ in the interactive matrix, number 0 would be assigned to the corresponding cell in the access matrix; then number 0 would be assigned to the symmetric cell, i.e. the cell $(i, j)$.

C:Creating the Final Matrix of Achievement: Considering the interactive relationship between the elements, the initial matrix of achievement needs to be adapted. For this reason, the initial matrix should be to the power $\mathrm{k}+1$ in order to fix the stable situation $\left(\mathrm{M}^{\mathrm{k}}=\mathrm{M}^{\mathrm{k}+1}\right)$. Therefore, some zero elements are converted to 1 and are shown as $\left(1^{*}\right)$.

\section{D:specifying the Relationships and the Levels Between Dimensions:}

After specifying the set to be accessible (output) and the primary set (input) for each element and specifying the accessible set (a set in which the lines are appeared as 1) for each element and the primary set (a set in which the columns are appeared as 1) or achieving the overlapping set of these two sets, the overlapping set will be achieved. Elements which exist in both accessible set and overlapping set take the first level of priority. If one element is deleted and the same is repeated for other elements, the level of all elements will be specified. According to the specified elements and the final accessible matrix, the research design was drawn. It is to notify that in the present research, the opinions of 7 experts were used to fill in the questionnaire of interpretive structural equations. Influence-dependency power analysis, the linear addition of final accessible matrix for each member indicates the extent of influence and the column addition indicates the extent of dependency. As a result, four groups of the elements including autonomous, independent, and joint and dependent variables can be identified.

Step 3:Presenting a comprehensive model for organizational voice: After testing and confirming the model, this new concept can be applied by the universities.

Table 2: Dimensions and Items of Organizational Voice (Source: Authors' elaboration)

\begin{tabular}{ll}
\hline $\begin{array}{l}\text { Organizational } \\
\text { Structure }\end{array}$ & Lack of skills standardization \\
& $\begin{array}{l}\text { Establishing an upward } \\
\text { communication }\end{array}$ \\
process formalization & Number of rules and regulations \\
& Lack of job-sharing
\end{tabular}

Management Shared management

Trusting management

Trusting management

Human

Resource

Employees with an
upward orientation

Permanent employees versus temporary employees

Employees reward

Employees performance

Group and $\quad$ Team interactions
Team

Character

Self-confidence

Lack of emotional stability

Lack of independence and decision- making

Self-efficacy

Empowerment

Motivation
Motivation to help organization 
HOSSEINI \& SABOKRO, Journal of Business Strategy Finance and Management,

Vol. 03(1-2) 34-47 (2021)

Human resource cooperation

Group size and structure



Market status

Organization culture

Power structure

Career security

Career risk

Career stress

\section{Supporting employees' rights}

\author{
Loyalty
}

Solving organization problems

Agreement with organization goal

Shared profit

Communication with
management

participation in decision making

Tendency to communicate with

.

Quality of relationship between

Motivation to control

Lack of delegation

Lack of commitment and job

satisfaction

Lack of financial welfare

\section{Occupational Features \\ Environment

Occupational
Features

\section{Research Finding}

The codes approved by the experts were included in a questionnaire with a 5-point Likert scale. After taking the average of the codes, the codes that had an average above 2.5 were confirmed for component classification (Table 2).

As it can be seen in Table 2, 10 dimensions including organizational structure (dimension 1 with 5 elements), management (dimension 2 with 2 elements), group and team (dimension 3 with 3 elements), voice environment (dimension 4 with 5 elements), occupational features (dimension 5 with 4 elements), human resource (dimension 6 with 4 elements), character (dimension 7 with 5 elements), motivation (dimension 8 with 5 elements), communication (dimension 9 with 4 elements), conflicts (dimension 10 with 4 elements) were accepted.
According to what we mentioned above, on first step, researchers specified effective factors on organizational voice in different levels after reviewing the background in the related field. As the factors were identified indistinctly and in a disorganized way from different researchers, they were required to be organized so that the research aim would be achieved. As a result, 10 factors were identified after making a central group by university experts and they are displayed in Table 3.

After 10 final factors were identifies, researchers started to design the questionnaire interpretive structural modeling among experts of Yazd University. The structural interactive matrix was achieved after data collection and elaborating on mode method based on the value which appears the most often. 
Vol. 03(1-2) 34-47 (2021)

Table 3: Identified Factors Influencing the Organizational Voice (Source: Authors' elaboration)

\begin{tabular}{|c|c|c|}
\hline No. & Factors & References \\
\hline 1 & Organizational Structure & $\begin{array}{l}\text { Morrison (2011); Pyman et al. (2006); Wilkinson \& Fay(2011); } \\
\text { Marchington et al. (2001); Kaufman (2015); Donaghey et al. (2011) }\end{array}$ \\
\hline 2 & Management & Park \& Nawakitphaitoon(2018); Tangirala \& Ramanujam (2012) \\
\hline 3 & Group and Team & $\begin{array}{l}\text { Turnbull (2003); Dundon (2002); Kaufman \& Taras (2010); Harrison } \\
\text { \& Freeman (2004); Wilkinson et al. (2013); Strauss (2006); Gollan } \\
\text { \& Wilkinson (2007); Welbourne (2011); Park \& Nawakitphaitoon } \\
\text { (2018); Morrison (2011); Marchington(2008); Freeman et al. (2007) }\end{array}$ \\
\hline 4 & Voice Environment & $\begin{array}{l}\text { Aryee et al. (2017); Park \& Nawakitphaitoon (2018); Van Dyne \& } \\
\text { LePine (1998); Morrison(2011); Kaufman(2015) }\end{array}$ \\
\hline 5 & Occupational Features & Morrison(2011); Bashshur \& Oc (2015) \\
\hline 6 & Human Resource & Tangirala et al. (2013); Kaufman(2015); Aryee et al. (2017) \\
\hline 7 & Character of Job & Aryee et al. (2017) \\
\hline 8 & Motivation & Kaufman(2015); Wilkinson et al. (2010); Morrison(2011) \\
\hline 9 & Communication & $\begin{array}{l}\text { Morrison(2011); Park \& Nawakitphaitoon (2018); Botero \& Van Dyne } \\
\text { (2009); Burris et al. (2008); Van Dyne et al. (2008) }\end{array}$ \\
\hline 10 & Conflicts & $\begin{array}{l}\text { Lewin \& Mitchell (1992); Pfeffer \& Jeffrey (1998); Morrison (2011); } \\
\text { Welbourne (2011); Wilkinson et al. (2010); Kaufman(2015); Burris } \\
\text { et al. (2008); Budd (2004); Boxall(2007); Kochan (1994); Budd } \\
\text { \& Zagelmeyer (2010); Budd et al. (2010) }\end{array}$ \\
\hline
\end{tabular}

The initial accessible matrix was made and the final accessible table was achieved that is displayed in Table 4.

\section{Specifying the Level of Dimensions}

The accessible, primary, and overlapping sets must be identified in order to specify the level of dimensions in accordance with what we mentioned in the previous section and it is indicated in Table 5.
Drawing the Interpretive Structural Model and Influence-Dependency Power Graph

According to table 6 and interpretive structural model, the Figure 2 was drawn. As it's been specified in the following Figure, organizational structure is categorized into 5 levels.

Table 4: Final Accessible Matrix (Source: Authors' elaboration)

\begin{tabular}{|c|c|c|c|c|c|c|c|c|c|c|c|}
\hline Elements & os & MA & GT & EN & CJ & HR & $\mathrm{CH}$ & MO & $\mathrm{CO}$ & CON & Influence \\
\hline $\begin{array}{l}\text { Organizational } \\
\text { Structure (OS) }\end{array}$ & 1 & 0 & 1 & $1^{\wedge *}$ & $1^{\wedge *}$ & 1 & 0 & $1^{\wedge *}$ & 1 & 1 & 8 \\
\hline Management (MA) & 1 & 1 & 1 & 1 & 1 & 1 & 0 & 1 & 1 & 1 & 9 \\
\hline Group and Team (GT) & 0 & 0 & 1 & $1^{\wedge *}$ & 1 & 1 & 0 & 1 & $1^{\wedge *}$ & 1 & 7 \\
\hline Environment (EN) & 0 & 0 & 0 & 1 & 0 & 0 & 0 & 1 & 0 & 1 & 3 \\
\hline $\begin{array}{l}\text { Characteristics of } \\
\text { the Job (CJ) }\end{array}$ & 0 & 0 & 1 & 1 & 1 & 1 & 0 & 1 & 1 & 1 & 7 \\
\hline Human Resource (HR) & 0 & 0 & 1 & 1 & $1^{\wedge *}$ & 1 & 0 & 1 & 1 & 1 & 7 \\
\hline Character $(\mathrm{CH})$ & $1^{\wedge *}$ & 1 & 1 & 1 & $1^{\wedge *}$ & 0 & 1 & 1 & 1 & $1^{\wedge *}$ & 9 \\
\hline Motivation (MO) & 0 & 0 & 0 & 0 & 0 & 0 & 0 & 1 & 0 & 0 & 1 \\
\hline Communication (CO) & 0 & 0 & 1 & 1 & $1^{\wedge *}$ & $1^{\wedge *}$ & 0 & 1 & 1 & 1 & 7 \\
\hline Conflict (CON) & 0 & 0 & 0 & 0 & 0 & 0 & 0 & 0 & 0 & 1 & 1 \\
\hline Dependence & 3 & 2 & 7 & 8 & 7 & 6 & 1 & 9 & 7 & 9 & \\
\hline
\end{tabular}


HOSSEINI \& SABOKRO, Journal of Business Strategy Finance and Management,

Vol. 03(1-2) 34-47 (2021)

Table 5: Specifying the Levels of the Model (Source: Authors' elaboration)

\begin{tabular}{|c|c|c|c|c|}
\hline Elements & Accessible set & Primary set & Overlapping set & level \\
\hline os & $\begin{array}{l}\text { OS,GT,EN,CJ,HR, } \\
\text { MO,CO, CON }\end{array}$ & $\mathrm{OS}, \mathrm{MA}, \mathrm{CH}$ & os & 4 \\
\hline MA & $\begin{array}{l}\text { OS,MA,GT,EN,CJ, } \\
\text { HR,MO,CO, CON }\end{array}$ & $\mathrm{MA}, \mathrm{CH}$ & MA & 5 \\
\hline GT & $\begin{array}{l}\text { GT,EN,CJ,HR,MO, } \\
\mathrm{CO}, \mathrm{CON}\end{array}$ & OS,MA,GT,CJ,HR,CH,CO & GT,CJ,HR, CO & 3 \\
\hline EN & $\mathrm{EN}, \mathrm{MO}, \mathrm{CON}$ & OS,MA,GT,EN,CJ,HR,CH,CO & EN & 2 \\
\hline CJ & $\begin{array}{l}\text { GT,EN,CJ,HR,MO, } \\
\mathrm{CO}, \mathrm{CON}\end{array}$ & $\mathrm{OS}, \mathrm{MA}, \mathrm{GT}, \mathrm{CJ}, \mathrm{HR}, \mathrm{CH}, \mathrm{CO}$ & GT,CJ,HR, CO & 3 \\
\hline HR & $\begin{array}{l}\text { GT,EN,CJ,HR,MO, } \\
\mathrm{CO}, \mathrm{CON}\end{array}$ & OS,MA,GT,CJ,HR,CO & GT,CJ,HR, CO & 3 \\
\hline $\mathrm{CH}$ & $\begin{array}{l}\text { OS,MA,GT,EN,CJ, } \\
\mathrm{CH}, \mathrm{HR}, \mathrm{MO} \text {, }\end{array}$ & $\begin{array}{l}\mathrm{CH} \\
\mathrm{CO}, \mathrm{CON}\end{array}$ & $\mathrm{CH}$ & 5 \\
\hline MO & MO & $\mathrm{MA}, \mathrm{GT}, \mathrm{EN}, \mathrm{CJ}, \mathrm{HR}, \mathrm{CH}, \mathrm{MO}, \mathrm{CO}$ & MO & 1 \\
\hline $\mathrm{CO}$ & $\begin{array}{l}\text { GT,EN,CJ,HR,MO, } \\
\text { CO, CON }\end{array}$ & OS,MA,GT,CJ,HR,CHCO & GT,CJ,HR, CO & 3 \\
\hline CON & $\mathrm{CON}$ & OS,MA,GT,EN,CJ,CH,HR,CO, CON & CON & 1 \\
\hline
\end{tabular}

The elements of influence and dependency of final accessible matrix (Table 4) has been used to draw



Fig. 2: Organizational Voice Model (Source: Authors' elaboration)

\section{Discussion}

As the aim of the article is to design a conceptual model of organizational voice with an Interpretive Structural modeling approach at Yazd University, the present study intends to design a conceptual model of organizational voice at Yazd University using qualitative methods. First, researchers reviewed the literature related to organizational voice, then they extracted the elements from the literature section of the articles and 15 factors were identified from all those articles. As identified factors were arranged influence-dependency power graph and it's shown in Figure 3.

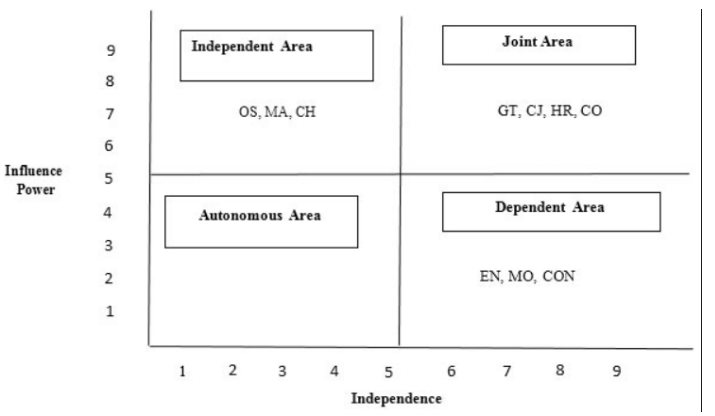

Fig. 3: Influence-dependence Graph (Source: Authors' elaboration)

indistinctly and in a disorganized way, researchers started to arrange them in order to equalize the conceptions by making a central group of 7 . As a result, the final factors influencing organizational voice decreased to 10 factors and categorized into 5 levels. Considering the identified dimensions can lead to the emergence of voice in service organizations. According to figure 3 , in addition to factors identity, we can understand the variables better. The following analysis can be achieved according to figure 3 : 


$$
\text { Vol. 03(1-2) 34-47 (2021) }
$$

\section{Autonomous Area}

Dimensions which have a weak influence-dependency power. These variables are approximately separated from the model, because they have a weak connection to mode; in the model of the present study, these dimensions do not exist and it shows the strong relationship between dimensions in organizational voice model.

\section{Dependent Area}

Dimensions which have a weak influence but strong dependency power. These dimensions are mostly the product of the model and there are many factors contributing to create them but they seldom provide contribution to other variables. In the present model, the dimensions of environment, motivation and, conflict are located in this area.

\section{Joint Area \\ Dimensions which have a strong influence- dependency power. They don't have a stability and the changes influence them and other variables. According to the results of the present study, the dimensions of group and team, characteristics of the job, communications, and human resource are located in this area.}

\section{Independent Area}

Dimensions which have a strong influence but weak dependency power. These dimensions are considered to be the key variables that constitute infrastructure of the model and they need a great deal of attention on first stage in order to start the system operation. In the present model, the dimensions of management, character, and organizational structure are located in this area.

Considering the importance of the independent area in Figure 3 and according to Figure 2, we can attract the managers' attention towards character, management, and organizational structure in order to achieve the organizational voice.

\section{Conclusion}

Employee voice is considered to be important because the ideas are not only presented by senior managers in the competitive and dynamic environment of today's organizations (Crant, Kim\& Wang, 2011). The background and review literature prove that the supportive behavior of the manager reduces the risk of destructive behavior and paves the way for employee voice to happen (Gu et al., 2015). Brown et al. (2005) also asserted that expressing the problems by employees can lead to the risk of negative results such as vengeance by the managers. But if employees trust the managers' trustworthy and good morals which are the characteristics of ethical leadership, the mentioned risk is reduced and employees more likely express their opinions (Brown, Treviño, \& Harrison, 2005). Managers can have a flexible reaction in high competitive and chaotic environment and prevent crisis in their organizations when they are accompanied by the employees. The qualitative and quantitative aspects must be taken into consideration when designing a job. The quantitative aspect deals with the volume of duties in that job and the qualitative aspect deals with the conditions at the workplace (Islam et al., 2019). Managers are believed to influence both aspects by appreciating the employees' welfare (Stouten, Baillien, Van den Broeck, Camps, De Witte \& Euwema, 2010). Managers increase career security and organizational identity of employee voice by developing the cooperation between employees (McKay, 2014). It seems that when professional employees have a feeling of uniqueness with their affiliated organization (or organization identity) affects their reciprocating behaviors by influencing their comprehensive relationships with their managers (Boivie, Lange, McDonald \& Westphal, 2011). Thus, presence at the workplace for long hours or on holidays may lead to create obstacles against meeting expectations and eventually to create conflict between roles and lack of balance 

Vol. 03(1-2) 34-47 (2021)

between work and life. A great deal of duties for qualified employees is a complicated issue because it can prevent them from doing the given duties well and lose their focus for fulfilling their functions optimally. In these organizations, employees try to achieve organizational goals beyond their roles. Finally, it can be concluded that giving the permission of employee voice provides loyalty, commitment and more cooperation in decision-making processes. Organizational voice can lead to continuous improvement and adaptation with the environment.

\section{Suggestions}

By the use of authority delegation and decentralization, managers can create a voice environment where employees are able to express their opinions. The preventive rules and regulations need to be adjusted. By applying the required mechanisms for arrangement between the activities may lead to expressing pure ideas by employees. Guidelines can be made for employees to cooperate more in decision-making in order to develop and improve the positive voice activities in organization.

\section{Acknowledgment}

The authors would like to express their sincere gratitude to all the reviewers as well as the member of Yazd University for their insightful comments in this study.

\section{Funding}

The author(s) received no financial support for the research, authorship, and/or publication of this article.

\section{Conflict of Interest}

The authors do not have any conflict of interest.

\section{References}

1. Aloini, D., Dulmin, R., \& Mininno, V. (2012). Risk assessment in ERP projects. Information Systems, 37 (3), 183-199. https://doi. org/10.1016/j.is.2011.10.001

2. Bai, Y., Lin, L., \& Liu, J. T. (2019). Leveraging the employee voice: a multi-level social learning perspective of ethical leadership. The International Journal of Human Resource Management, 30 (12), 1869-1901. https://doi. org/10.1080/09585192.2017.1308414

3. Berman, E. M., West, J. P., \& Richter, J., Maurice
N. (2002). Workplace relations: Friendship patterns and consequences (according to managers). Public administration review, 62 (2), 217-230. https://doi.org/10.1111/00333352.00172

4. Boivie, S., Lange, D., McDonald, M. L., \& Westphal, J. D. (2011). Me or we: The effects of CEO organizational identification on agency costs. Academy of management journal, 54 (3), 551-576. https://doi.org/10.5465/ amj.2011.61968081

5. Bordbar, G., Monfared, A. K., Sabokro, M., Dehghani, N., \&Hosseini, E. (2021). Human resources competencies scale development and validation: an Iranian measure. Industrial and Commercial Training.ahead of print.https:// doi.org/10.1108/ICT-03-2020-0028

6. Brinsfield, C. T., Edwards, M. S., \& Greenberg, J. (2009). Voice and silence in organizations: Historical review and current conceptualizations. Voice and silence in organizations, 1.

7. Brown, M. E., Treviño, L. K., \& Harrison, D. A. (2005). Ethical leadership: A social learning perspective for construct development and testing Organizational behavior and human decision processes, 97 (2), 117-134. https://doi. org/10.1016/j.obhdp.2005.03.002

8. Crant, J. M., Kim, T.-Y., \& Wang, J. (2011). Dispositional antecedents of demonstration and usefulness of voice behavior. Journal of Business and Psychology, 26 (3), 285-297. https://doi.org/10.1007/s10869-010-9197-y

9. Detert, J. R., \& Burris, E. R. (2007). Leadership behavior and employee voice: Is the door really open? Academy of management journal, 50 (4), 869-884. https://doi.org/10.5465/ amj.2007.26279183

10. Donaghey, J., Dundon, T., \& Freeman, R. B. (2014). Handbook of Research on Employee Voice: Edward Elgar Publishing.

11. Dundon, T., \& Gollan, P. J. (2007). Reconceptualizing voice in the non-union workplace. The International Journal of Human Resource Management, 18 (7), 1182-1198. https://doi.org/10.1080/09585190701391925

12. Dyne, L. V., Ang, S., \& Botero, I. C. (2003). Conceptualizing employee silence and employee voice as multidimensional constructs. Journal of Management Studies, 40 (6), 13591392.https://doi.org/10.1111/1467-6486.00384

13. Fornell, C., \& Larcker, D. F. (1981). Evaluating 
structural equation models with unobservable variables and measurement error. Journal of marketing research, 18 (1), 39-50. https://doi. org/10.1177\%2F002224378101800104

14. Gambarotto, F., \& Cammozzo, A. (2010). Dreams of silence: Employee voice and innovation in a public sector community of practice. Innovation, 12 (2), 166-179. https:// doi.org/10.5172/impp.12.2.166

15. Gu, Q., Tang, T. L.-P., \& Jiang, W. (2015). Does moral leadership enhance employee creativity? Employee identification with leader and leader-member exchange (LMX) in the Chinese context. Journal of business ethics, 126 (3), 513-529. https://doi.org/10.1007/ s10551-013-1967-9

16. Hosseini, E., SAEIDA ARDEKANI, S., \&Sabokro, M. (2020a). Conceptual model of the voice of the members of the scientific board of public universities of Iran with the approach of interpretive structural modeling. Journal of Research on Management of Teaching in Marine Sciences.7 (4), 16-41.

17. Hosseini, E., SaeidaArdekani, S., \&Sabokro, M. (2020b). Presentation the Pattern of Knowledge Employees Voice (Case Study: Shiraz Gas Company Employees). Quarterly Journal of Public Organzations Management, 8(4), 57-72.

18. Hosseini, E., SaeidaArdekani, S., Sabokro, M. (2021a). Investigating the Leadership Integrity on the Voice of the Employees by Mediating the Empowering Behaviors of the Leader (A case study: Yazd Travel Agencies). Journal of Tourism and Development, ahead of print. https://doi.org/10.22034/jtd.2020.212471.1915

19. Hu, Y., Zhu, L., Li, J., Maguire, P., Zhou, M., Sun, H., \& Wang, D. (2018). Exploring the influence of ethical leadership on voice behavior: how leader-member exchange, psychological safety and psychological empowerment influence employees' willingness to speak out. Frontiers in psychology, 9, 1718. https://doi.org/10.3389/ fpsyg.2018.01718

20. Islam, T., Ahmed, I., \& Ali, G. (2019). Effects of ethical leadership on bullying and voice behavior among nurses: mediating role of organizational identification, poor working condition and workload. Leadership in Health Services, 32 (1), 2-17.

21. Islam, T., Ahmed, I., Ali, G., \& Sadiq, T. (2016). Behavioral and psychological consequences of corporate social responsibility: need of the time. Social Responsibility Journal, 12 (2), 307-320. https://doi.org/10.1108/SRJ-04-2015-0053

22. Kalshoven, K., Den Hartog, D. N., \& de Hoogh, A. H. (2013). Ethical leadership and followers' helping and initiative: The role of demonstrated responsibility and job autonomy. European Journal of Work and Organizational Psychology, 22 (2), 165-181. https://doi.org/10.1080/13594 $32 X .2011 .640773$

23. Kim, J., MacDuffie, J. P., \& Pil, F. K. (2010). Employee voice and organizational performance: Team versus representative influence. Human Relations, 63 (3), 371-394. https://doi.org/10.1177\%2F0018726709348936

24. Kim, M., Choi, L., Borchgrevink, C. P., Knutson, B., \& Cha, J. (2018). Effects of Gen Y hotel employee's voice and team-member exchange on satisfaction and affective commitment between the US and China. International Journal of Contemporary Hospitality Management, 30 (5), 2230-2248.https://doi.org/10.1108/ IJCHM-12-2016-0653

25. KonjkavMonfared, A., Hosseini, E. (2020). The Impact of Exploration and Exploitation Strategies on Tourism Brand Reputation With Emphasis on The Role of Loyalty and Mental Image of Tourists (Case Study: 4 and 5 Star Hotels In Yazd). Journal of Tourism and Development, 9(3), 191-206. https://doi.org/ 10.22034/jtd.2019.191017.1775

26. Maynes, T. D., \& Podsakoff, P. M. (2014). Speaking more broadly: An examination of the nature, antecedents, and consequences of an expanded set of employee voice behaviors. Journal of Applied Psychology, 99 (1), 87.

27. McKay, R. B. (2014). Confronting workplace bullying: Agency and structure in the Royal Canadian Mounted Police. Administration \& Society, 46(5), 548-572. https://doi. org/10.1177\%2F0095399713509245

28. Moaşa, H. (2011). Voice and silence in organizations. Bulletin of the Transilvania University of Braşov, Series VII: Social Sciences and Law (2), 33-40.

29. Nikraftar, T., Hosseini, E., \&Moghadam, A. (2017). Identify factors affecting medical tourism attraction in Iran. Journal of Health Administration, 20(67), 64-74.http://jha.iums. ac.ir/article-1-2138-en.html

30. Rai, A., \& Agarwal, U. A. (2017). Linking 
workplace bullying and work engagement: the mediating role of psychological contract violation. South Asian Journal of Human Resources Management, 4 (1), 42-71. https:// doi.org/10.1177\%2F2322093717704732

31. Rajabipoormeybodi, A., Hosseini, E., \& Ajorloo, F. (2019). Examining the Effect of Unlearning in the Organization on Human Resource Development. Iranian Society for Training and Development, 5(17), 137-157.

32. Ruck, K., Welch, M., \& Menara, B. (2017). Employee voice: An antecedent to organisational engagement? Public Relations Review, 43 (5), 904-914. https://doi.org/10.1016/j. pubrev.2017.04.008

33. Sabokro, M., Kayedian, A., \&Hosseini, E. (2021). Identifying retention Risks in Faculty Member. Journal of Research on Management of Teaching in Marine Sciences.8(1),1-17.

34. Sabokro, M., Tajpour, M., \&Hosseini, E., (2018). Investigating the knowledge management effect on managers' skills improvement. Int. J. Hum. Capital Urban Manage., 3(2): 125-132. https://
doi.org/10.22034/IJHCUM.2018.02.05

35. Sagnak, M. (2017). Ethical Leadership and Teachers' Voice Behavior: The Mediating Roles of Ethical Culture and Psychological Safety. Educational Sciences: Theory and Practice, 17 (4), 1101-1117. https://doi.org/10.12738/ estp.2017.4.0113

36. Salamzadeh, A., Tajpour, M., Hosseini, E., \& Salembrahmi,M. (2021).Human Capital and the Performance of Iranian Digital Startups: The Moderating Role of Knowledge Sharing Behaviour, International Journal of Public Sector Performance Management, Ahead of print.

37. Stouten, J., Baillien, E., Van den Broeck, A., Camps, J., De Witte, H., \& Euwema, M. (2010). Discouraging bullying: The role of ethical leadership and its effects on the work environment. Journal of business ethics, 95(1), 17-27. https://doi.org/10.1007/s10551-0110797-x

38. Tajpour, M., Hosseini, E., \&Alizadeh. R.,(2021). Entrepreneurship Opportunities: The Effect of Social Entrepreneurship on the Presence of 